\title{
The coin of morality
}

\author{
Mihaela BUCATARIU \\ The Bucharest University of Economic Studies, Bucharest, Romania \\ mihaela_bucatariu@yahoo.co.uk \\ Ioana Cristina FLORESCU \\ The Bucharest University of Economic Studies, Bucharest, Romania \\ ioanaflorescu2001@yahoo.com
}

\begin{abstract}
Looking for an idealization of the business environment, we notice that private businesses which have set ethic goals in business achieved a much higher profit growth rate than similar businesses that have not set business ethic codes. Of course, entrepreneurs decide their own interests and do not consider that the action of social responsibility has to be mechanical. In fact, if we consider a free-market capitalist system, the entrepreneur should have an ethical behavior in business or to choose a moral voluntary attitude. The present paper is looking to see if, in a material, rational and a no-matter-what profit oriented attitude world, a moral capitalism is possible to exist. By the more significant phenomena of globalization, entrepreneurs can be considered selfish people, performing immoral actions, with a predisposition of owning everything, without thinking at the old ideals. Nowadays, the entrepreneurs act only in the direction of getting the profit and very few of them have a moral motivation. The man in the modern capitalist world is looking only for his own interest in order to satisfy his desires and aspirations at a level as high as possible. A normal and natural thing, in fact. Therefore, no matter the role of the entrepreneur, there is the possibility to create cultural ways to solve ethical and social problems, and also methods that make moral capitalism principles to be functional, and, thus, a convergence between the free market and entrepreneurial ethics to be possible.
\end{abstract}

Keywords: entrepreneur, business ethics, moral capitalism, moral character, principles.

\section{Introduction}

We live today, we could say, in the era of new technology, an era that creates more personal comfort through the entrepreneurial environment.

At this moment, any consumer aims for nothing else than to meet his needs and the entrepreneurs by maximizing their profit follow their own interest regardless of the circumstances. This "summon bonum" represents the metaphorical framework of the capitalist system, while the socialism system is characterized by the prosperity of mankind, based on justice, equity and morality.

If we establish a complex ontology, capitalism is according to Hans-Hermann (2013): "a social system based on the explicit recognition of private property and of the non-aggressive contractual exchanges between private property owners." Therefore, this article aims to demonstrate the fact that regardless of the existing societies, which are capitalist and / or socialist, there is a deformation of entrepreneurship. This means that we have to impose some interpretations in order to build motives and processes, delimited by the two temporal systems based on descriptive and real existence. In fact, the character of the entrepreneur has changed from the consumer archeology to ultimately reaching somewhere else. This "somewhere else" will represent a choice for all these people who are free to decline their social responsibility to the extent they want it.

Starting from this false dialectic, the "moral capitalism" as it was named by Wallerstein, Randall, Mann, Derluguian, \& Calhoun (2015) inevitably brings in mind the 
image of the person seeking gain by any means but being an honorable and honorable thing. The dominance of entrepreneurial behavior will be focused on these moral values, the problem being the disappearance of certain elements and the appearance of others, reminding us, of course, that in the postmodern era the consumer was king, whereas now he tends to accept the offer imposed by the economic agent.

Any feasible business starts from the following: the initial capital, choosing the location and the company's headquarters, the employees, the making of the product or service, its pricing, its launching, promoting and satisfying the needs of the potential customers. Obviously, these components take place through everyone's interaction, which typically involves their adaptation and integration which have as a goal to ensure people's prosperity.

However, capitalism has an imperialist interest, providing us in a mechanical way with the means of living, but it has other multiple interests, which are related to religion (awareness), objectives, honesty, education, etc.

On the other hand, capitalization is a word invented by Marx, and the main drivers of business change are the introduction of new technologies, information and communication, the introduction of regulatory, privatization and liberalization policies. This world results in a world of inequality and conflict. The paradox lies in the fact that the global companies that demand regulatory policies use their superior competence by adopting a monopolistic power in order to capture international institutions such as the IMF, the World Bank, with the ability to influence even government policies.

However, some characters express through a severe cry that there is a majority arrangement influencing the behavioral ethical choice of the economic agent penalizing the powerless as seen in the books written by Thaelr (2015) and Morar, Crăciun, \& Macoviciuc (2016).

No world can be described exhaustively but we can try to describe the world as being made of entity and property, the entity is formed of a possible world and the second one through the manipulation of the entities and properties of the former. This hidden manipulation captures the suffering of human behavior that has become more and more impersonal. In order to overcome certain difficulties they are related to morality, the world economy needs a new global ethic. The socially built reality is a puzzle of humanity that must change its vision from the fact that a society cannot exist without morality.

\section{Literature review}

From a historical point of view, business has been done for at least 6 millenniums. The first significant moment in the history of business ethics was represented by the Sumerians, who have also left documents in this regard. The famous book "History Begins at Sumer" was stating that "goods exchange implied minimum behavior rules between the participants in this type of activity". But in trade-off, for example, Aristotle showed there were two ways: one of them, oikonomikosi, which he approved and considered to be essential to the economic activity, even for a modern society, and the other one was chrematisike, as being completely without virtue, naming them as "parasites". These parasites are people from society's periphery who engage in practices of lending out money at interest, these being unproductive and being common even in nowadays.

Another economist, Robert C. Solomon, shows that the expression of "motivation for profit" has a depreciative tone. He was underlying that "chasing the profit is rather one of multiple goals". Thus, the profit should represent for entrepreneurs a mean and 
not a goal itself. By chasing and getting the profit in any possible way, it can be interpreted that business is immoral or amoral.

If we come back to the globalization era, we notice that moral practices have an emphasized tendency, more vocal because the entrepreneur is not isolated anymore, as he has during the communist era.

The most common quote, having a broader significance, is the famous phrase of Milton Friedman, stating that "the social responsibility of business is to increase its profits". This social responsibility concept is a moral notion that coagulates both the idea of some virtues involved in entrepreneurial environment (honesty, utility, sincerity, transparence), but also the idea that there are economic agents with moral and social concern.

The next step for economic agents would be to become aware of the need to provide quality products and services without disturbing the traffic, casting away natural resources or destroying the environment.

\section{Methodology}

The methodology used by us, the authors was a qualitative one. In order to prove if a moral capitalism can exist in the world we used a large amount of books which refer to this topic amongst other sources that refer to the three perspectives of capitalism: the model of traditional Chinese capitalism, the model of greed and social Darwinism and the one that is based on gaining advantages and privileges but with a non-economic influence. All of them are described and commented in the paragraphs below.

The complexity of the socio-psychological characteristics in the entrepreneurial environment, which resides above all from its heterogeneous existence, existing autonomous, has been elucidated to a certain extent by Stephen Young by defining some models of capitalism.

In his book, „Moral capitalism” Stephen Young (2009) illustrates the 3 models, first of all, the model of the traditional Chinese capitalism based on an ideal of order, peace and harmony. "China's business environment was based on an outdated production system operating within a guaranteed competitive environment. Chinese companies use the price as a competitive advantage, to the detriment of quality, the treatment of the employees is an authoritative paternalist, there is no transparency on financial information and the market is controlled by cartels."

In conclusion, this traditional value model in China results in a sustainable development with little innovation and, of course, a lot of corruption.

The second model is considered a form superior to capitalism, having an ideal based on greed and social Darwinism.

In truth, the wild business environment is abusing market forces and the weaker will fail.

It is important to note, however, that this form represents according to Stephen (2009)" an unrestricted freedom to sell and buy, it is the supreme value, because it creates the greatest benefit through competition." There is of course a capitalism based on human creativity, which brings benefits to humanity. Instead, aggression is defined as an invasion of value through price control, regulation, and behavioral control, regardless of the interests and expectations of others.

Consequently, applying these standards has resulted in the loss of equity investments, financial losses for employees, creditors and suppliers.

The third model is represented by gaining advantages and privileges but with a non-economic influence. Of course, the model is dominated by kindred relation, but also 
by the involvement of some politicians by sharing profits among a small number of beneficiaries. We would not exaggerate if we characterized the dominant power as a form of oligarchy. "The principles under which this system works are gaining favors, purchasing governmental decisions, and controlling the economy through the police, not through market and election mechanisms." In conclusion, this type of capitalism is based on a type Mafia administration and there is a large-scale transfer to the elite families of the regime.

\section{Creation and fall}

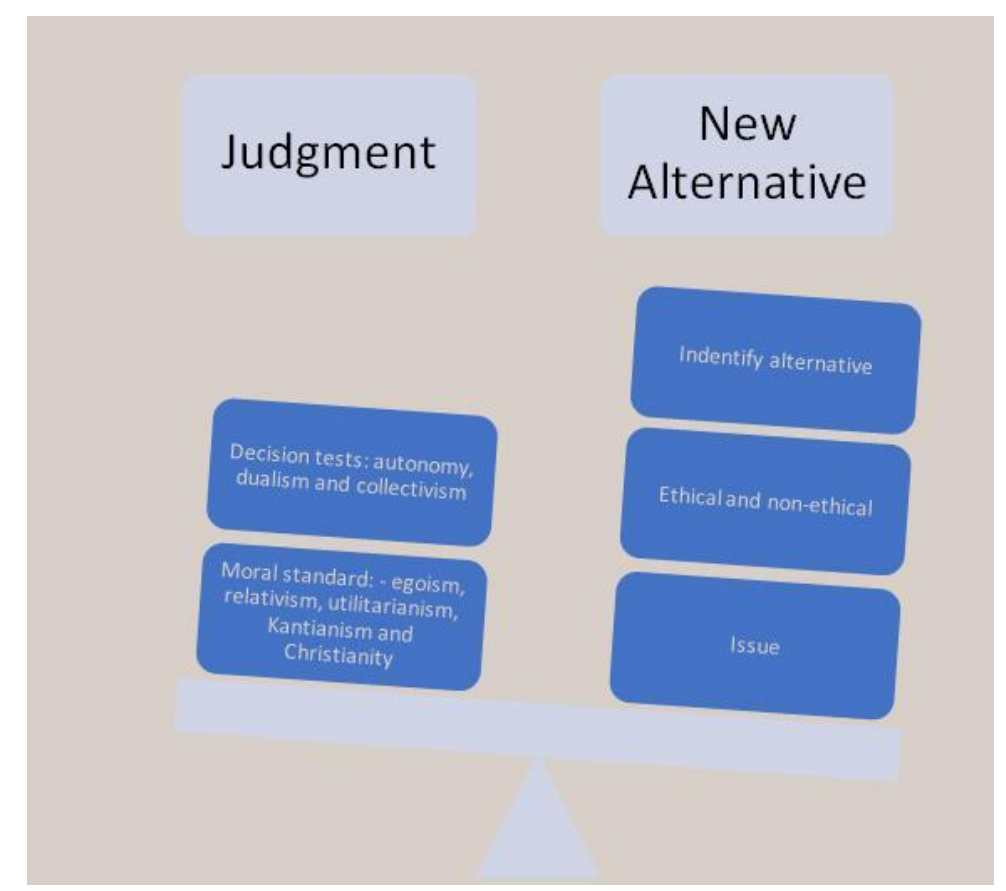

Figure 1. The standard model regarding the moral capitalism

Source: Authors' own research.

According to this model, we distinguish the two generic frameworks:

1. Principles that support ethical behavior

- Utilitarianism

- Kantianism

- Christianity

2. Attitudes that don't respect ethical behavior

- Selfishness

- Relativism

\section{Utilitarianism}

Utilitarianism, initiated by Bentham (1907) and restructured by Stuart (1994) where they claim that "actions are correct to the extent that they tend to promote happiness and are incorrect as they tend to produce the reverse of happiness. Through happiness it is understood the the pleasure or absence of pain, through misery, the pain and absence of pleasure." This utility can be said to be fair or rather the effort we perceive as being invested in the search for this motto. Highlighting the problem of utilitarianism in the entrepreneurial environment would be the fact that if the total amount of benefits is greater than the total amount of ethical actions then the action that person takes is DOI: 10.2478/picbe-2018-0016, pp. 161-170, ISSN 2558-9652| Proceedings of the $12^{\text {th }}$ International Conference on Business 
beneficial only if the net benefits are greater for all people affected by the action. In conclusion, a fact blamed by someone can be morally justified if it determines, on the long term, favorable consequences for the majority.

\section{Kantianism}

In this respect, Kant (1972) "researched the non-contingent moral principles and demonstrated that an action has full moral content only if done in agreement and respect for a universally valid principle and necessary for any rational being."

Kant developed a special principle that can be explained and implemented in the business world by "categorical imperatives". In short, Kant proposes the following formulas: (i) universality; (ii) reversibility and (iii) respect.

The universality was formulated by Kant (1972) through his categorical imperative: "Act only according to that maximum, whereby you can will that is should become a universal law without contradiction."

Starting from this idea, we find that if this rule was applied universally it would be self-destructive, and consequently the action would be immoral.

However, we can assume that we do the following: for example we drive a car on a crowded road. Leaving the external action unchanged, meaning that nothing urgent interferes (police, fire, rescue), but interpolating some supposed situations, we realize that because of our selfishness we calculate our personal interest for saving the time we need to get on time. In this case, utilitysm determines the net benefits for those affected, taking into account our own needs (the important meeting) against possible prejudice to others as a result.

In other words, universalism is a fundamental characteristic of morality.

As it is well known in the entreprenorial environment, no matter the results obtained from the false presentation of a product, this can not be justified according to the Kantian principle because it is based on a lie. So, by introducing the Kantian ethics prnciples, business decisions will represent a human necessity.

In conclusion, the empirical universality is nothing but an arbitrary construction of validity, for example, in court, the entrepreneurs want a maximum profit, and this knowledge of the human judgement is necessary for them to reach their gools, these being conditioned by the competitive environment.

\section{Christianity}

Dostoevsky (2011) said in his book that "if God does not exist, everything is permitted". The religious belief shapes the morality in the entrepreneurial environment in two ways: either through the deviation from the through word of faith and the adoption of some moral concessions, imposed by emancipation, or the zealot fanaticism which is less and less compatible with the ethical horizon of a dynamic world, which is in progress of globalization.

\section{Reversibility}

Once we have identified the dominance of universality, we can begin to describe the reversibility that is directly related to the former. The universality of the reasons for our decisions is designed in such a way that we are willing to make others act in the same way.

In the entrepreneurial environment, this reversibility is applied by the golden rules which consist in creating a good example for others, but we do not know for sure in they are always being analyzed morally. Mc Donald's(2017) company has designed a 
golden rule: "treat others as yourself" by assuming by each employee the responsibilities and tasks to create a quick service to customers and an unforgettable experience.

Despite what I have said above, there is a part affected directly or indirectly by the actions or decisions of the entrepreneurs because sometimes they trick their clients in order to get the maximum profit.

Kant (1972) states that we should act, by the principle of respect, "act by using humanity, both in your person, but also in everybody else's, always in the same time as a purpose, but never only as a mean."

\section{Respect}

The third statement of the "categorical imperative" is based on Kant's assumption, according to which we should treat people as purposes themselves, not in the typical way with the charge of prejudices of mimetic nature.

In business, the entrepreneurs treat their potential clients as a "means" they manipulate and exploit for their own interest. Such an action leads towards the benefits got by the entrepreneurs, in an illicit and immoral way, but also by exploiting the employees, although on the long run this improves the general well-being of the business.

\section{Putting it all together: a normative framework for an ethical decision}

Let's build a world composed of three entrepreneurial aspects, the first one based on fierce capitalism, the second one described by a traditional capitalism and the last one by a social Darwinism.

This corollary proves a closed and ordered vision and is focused on man's action and his character regarding these topics.

The entrepreneur effectively transforms himself into something else because he is looking for a foundation, the maximization of profit.

Willy-nilly, we are going to create a matrix with four possible scenarios because this is needed in order to admit a certain type of superposition or interpretation between the moral and non-moral action. 


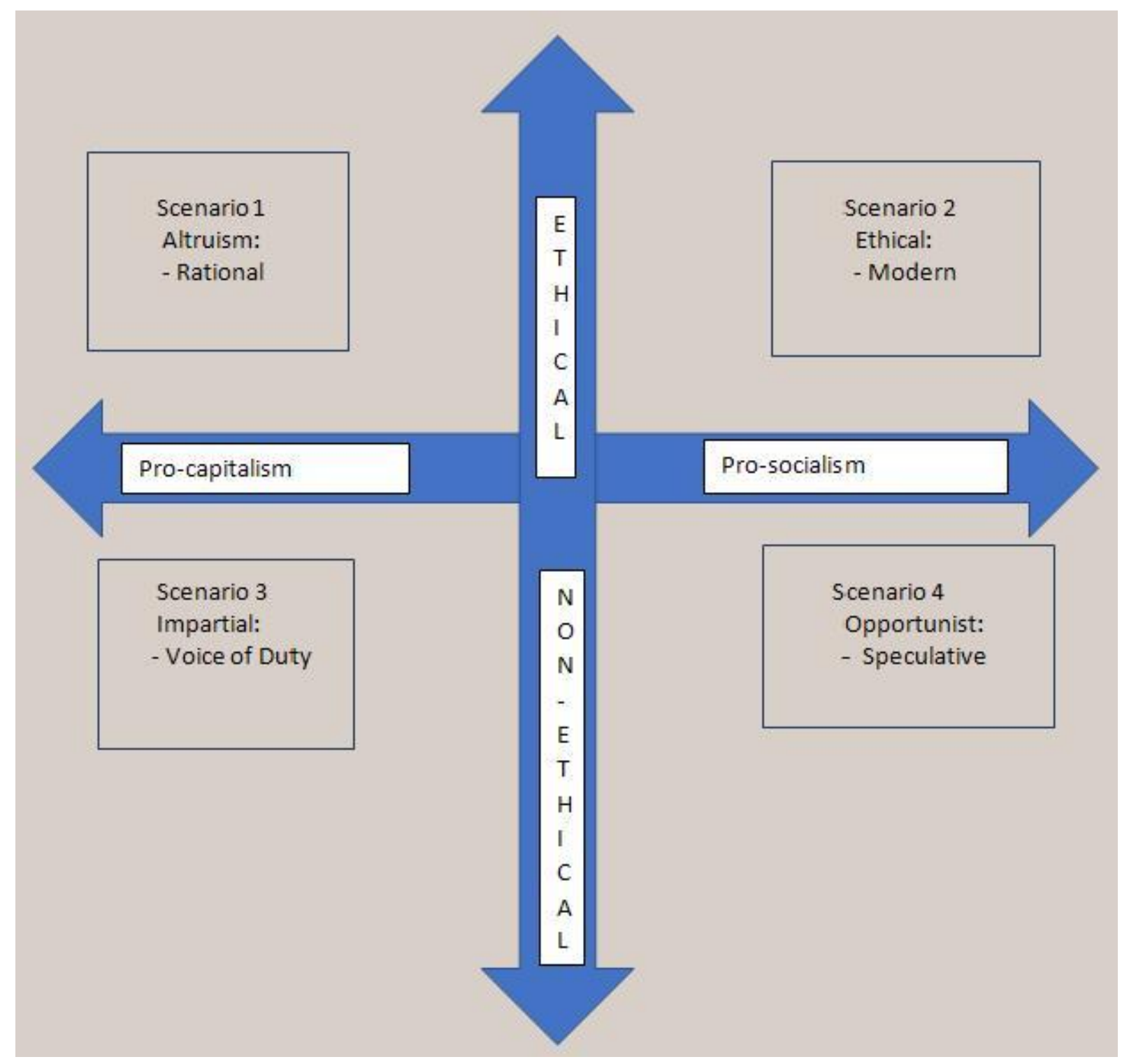

Figure 2. Matrix with scenarios regarding entrepreneurial behavior

Source: Authors' own research.

Scenario 1: The altruist entrepreneur prefers to adopt a non-aggressive attitude through cooperation, communication and understanding, which rather leads to a democratic, self-improved behavior.

Scenario 2: The rational behavior of the entrepreneur implies approach of the goals with a spirit of initiative, work, willingness, motivation and compliance with the legal frame. The entrepreneur has to act by complying with the conditions which have been initially accepted as rules and norms in competitive relations.

In a functional market economy, the economic agents receive a good reputation and trust, which leads to a sustainable development, social growth and human dignity.

Scenario 3: The egoism is governed by a pragmatic realism, focused on the maximization of benefits, advantages and profits that the entrepreneur can obtain.

A business that doesn't have a minimum of morality, on long term, has few chances of success. An entrepreneur who treats his employees in an unfair way, who doesn't respect the contractual commitments with his suppliers or with the bank can be characterized as someone who lies, cheats or steals, an immoral person overall. 
Scenario 4: The opportunist entrepreneur mirrors the reality now more than ever. "In market development, nothing is holly".

As an organizational scheme, he lays on gigantic pyramids of debt due to the current crediting mechanism based on the creation of currency from nothing. This prosocialist system would be a wrong economic system, but it goes on by stealing the citizen, with the non-existence of a moral market (tax evasion, corruption, excessive bureaucracy, etc) which provides the opportunity for a minority group to get favors, exceeding the moral borders by showing their opulence and spoiling. Thus, this 'innocent' parody represents in fact greed which has been let free and unpunished. There is here at least an implied critics of the destabilisation and neat chaos that transfigures the entrepreneurial behavior.

In other words, the scheme outlined above is not an abstract exercise, it is actually an assembled model for our society. The four scenarios explain some features of the normal operations of a market economy in which people face moral problems such as "What are the characteristics - the sine qua non - of the capitalism as a system?, of the socialism as a system?"

Emphasizing the capitalism system is not, of course, a novelty promoted by postmodernism. This system already has a characteristic feature through profit-based production. Instead, the modern world systems have a "free" market mantra, but have never been exempt from government regulations, and more recently from populist policies. On the other hand, there is no country or region that strictly applies the pure pattern of the free market.

From our point of view, the main feature for the four scenarios would be the one of capital assimilation. Business judgments are based on uninterrupted capital accumulation without being morally bound.

In reality, these "free markets" are not competitive because they have quasimonopoly tendencies. This quasi-monopoly uses the power of the state in order to limit the entry of the other entrepreneurs to the market.

For example, Uber, theAmerican start-up offers transport services for citizens with a simple application for smartphone or tablet. The basic idea starts from sharing the means of transport used by the travelers to go in the same direction in order to consume less fuel and to de-congestion the crowded roads. Besides, it offers opportunities for all the people to have a flexible income in order to better balance work and family life.

From an economic point of view, it represents a model of market liberalization because this firm works absolutely transparent, having competitive prices and is fiscalized. Instead, the City Hall of Bucharest has recently tried to promote the other existing taxi companies in the market, thus creating monopoly privileges. The morality of this example, leaving aside protectionism and licensing regulations, car damping, etc., Uber offers prices that may fluctuate according to demand when other companies accept preferential travel or impose a non-taxed price.

Consequently, the notion of liberty could be consented as a source of collective benefit. This concept is the basis of a priori acceptance of the social responsibility function by extending personal interest to the collective one.

Thus, Joseph Scumpeter (2011) reaches the sensible capitalist chord in „Can capitalism survive?" stating that: "the opening of new markets, internal or external, and organizational development, from the handicraft and factory to the companies, illustrates the same process of industrial mutation - if you allow me to use this biological term - which continually revolutionizes the internal economic structure, destroying it 
without stopping the old one and permanently creating a new structure. This process of Creative Destruction is the essential aspect of capitalism. "Here, the entrepreneur leads a "guerilla war" against the current by designing a destructive reality.

The resistance to this creative destruction of the entrepreneurs is organized on the free market through an empirism that is incapable of compromise, which might be said to be in favor of military normality. In other words, the entrepreneur becomes confused, separating himself through a transparent and yet impenetrable barrier, failing to maintain the separation between opportunism and altruism. In the formulation of the socialism we find a centralized, populist, interventionist system which does not provide competition between economic agents in certain branches of the economy and there are no incentives for innovation.

\section{Result and discussions}

The complexity of the studied topic shows us there are no differences between the economic destiny and the person. This emphasizes the fact that between morality and non-morality there are some advantages and disadvantages that often show the two sides of the same coin.

Thus, the two tones will be the opportunities that provide the possibility to decide if "one could have done different" for the future of humankind:

- One decides too early and then the future stays the same;

- One decides too late and thus there is no chance to repair.

Among the two opportunities, the materialist critics and the moral attitude, the latter can influence the future through freedom, creation and innovation, intervening with natural actions so that the monstrous coin could fade away step by step.

Generally speaking, people evaluate their life after the market value, forgetting to make a distinction between morality and non-morality. This situation does not define in any way our moral duty because it does not regard us. Thus, if we made a distinction between the two sides of the coin, we could conclude that we have to resign and that everything depends on human will. The difficulty or, rather, the incompatibility between evolution and individual economic progress does not act at the formal level, but at the psychological one. The scene of the rational world mediated by evolution creates a shock in the mind of the materialist man who believes in an opulent life and has expectations from this. This topic continues to stay in discussion because it is a complex one and it is a frequently used model, but which we do not think it is legitimate from an epistemic point of view, because it can have at most a heuristic value.

\section{Conclusion}

What has been proposed in this paper, despite the limitations, we hope to be a point of debate in the ethical decision-making process and the stages we are going to go through in the entrepreneurial area.

The "free market" is influenced by the two forms: capitalism and socialism. In the semantics of the word virtue, we find the encouragement to become better people, but yet we have no established ethical character. Today's entrepreneurial culture considers getting a profit as high as possible at the expense of the customer (inferior products, executable services, short term use of products, etc.) exceeding the organizational values.

A solution to overcome these selfish characters would be to better develop consumer features in order to influence those immoral results. For example, the consumer only accepts tacit cooperation on unpalatable attitude, mimetic language and 
the kitsch products that define the culture of running an organization. People are witnessing repeated oscillations between pro-socialist and pro-capitalist economic arrangements that create an uncontrolled chaos of the main actors in the entrepreneurial field. We can include a third main actor: the state. It greatly influences the entrepreneurial environment through increasingly aberrant regulations and nondemocratic elections. The state can play a positive role without developing totalitarian tendencies and excessive bureaucracy.

Many firms exercise quasi-monopolies, where a single contractor is the owner of the enter public space in an entire region, a sector where it may affect the freedom of expression of the market (for example, Mega Image). Nevertheless, we would like to highlight, in conclusion, a few characteristics of the society that try to militate for altruism, sincerity, honesty, etc. These include the fact that: (ii) Creating a legal framework in public institutions regarding social responsibility; (iii) Entrepreneurs should again appeal to their moral values and insights from the start of the business (respecting the company's mission). We would also like to argue that there is the possibility of creating a better world through the cooperation and communication of all the individuals involved in this process.

\section{References}

Aristotel. (1988). Etica Nicomahică. Bucharest, Ştiinţifică şi Enciclopedică Publishing.

Bentham, J. (1907). An Introduction to the Principle of Morals and Legislation. Gloucestershire, Clarendon Press.

Mc Donald's (2017). Mc Donald's. Retrieved from http://mcdonalds.ro/lumeamcdonalds/companie.

Dostoevsky, K. M. (2011). Brothers Karamazov. Bucharest, Polirom Publishing.

Hans-Hermann, H. (2013). A Theory of Socialism and Capitalism, New second edition. New York, Ludwig von Mises Insitute.

Kant, I. (1972). Groundwork of the Metaphysics of Morals. Bucharest, Scientific Publishing House.

Morar, V., Crăciun, D., \& Macoviciuc, V. (2016). Business Ethic - concepts, theories, moral situations. Bucharest, Paideia Publishing.

Scumpeter, J. A. (2011). Can Capitalism Survive? Creative Destruction and the Future of the Global Economy. Bucharest, Publica Publishing.

Solomon, R. C. (1984). Ethics: A Brief Introduction. New York, Mc Graw-Hill Publishing.

Stephen, Y. (2009). Moral Capitalism: Reconciling Private Invest with the Public Good. Bucharest, Curtea Veche Publishing.

Stuart, M. J. (1994). Utilitarianism. Bucharest, Alternative Publishing.

Thaler, R. H. (2015). Misbehaving The Making of Behavioral Economics. Bucharest, Publica Publishing.

Uber. (2017). Uber helping cities. Retrieved from https://www.uber.com/ro/helpingcities/.

Wallerstein, I., Randall, C., Mann, M., Derluguian, G., \& Calhoun, C. (2015). Does Capitalism Have a Future? Bucharest, Comuncation Publishing. 